\section{IJDMT}

(C) I A E M E

\title{
EVOLUTION OF MICROSTRUCTURE IN MICROALLOYED STEEL UNDER CONTINUOUS COOLING
}

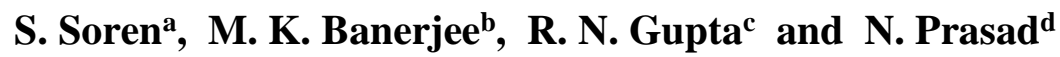

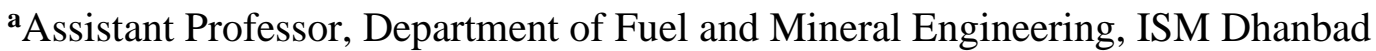

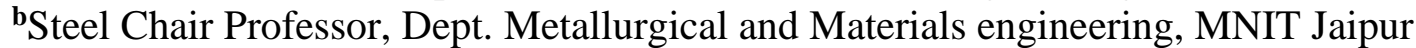 \\ ${ }^{\mathbf{c}}$ Associate Professor \& Head, Dept. of Metallurgical Engineering, BIT Sindri \\ ${ }^{d}$ Ex- Professor, Dept. of Metallurgical Engineering, BIT Sindri
}

\begin{abstract}
The evolution of microstructure under continuous cooling is studied with the help of transmission electron microscopic observation. It is found that the phase transformation in microalloyed steel is mechanistically transient. It is also observed that at the intermediate cooling rate, some austenite is retained in the microstructure. The microstructural evolution in a microalloyed steel was studied for verification and it is observed at the cooling rate 20$30^{\circ} \mathrm{C} / \mathrm{sec}$ chunky austenite is present in the microstructure. This austenite aids in improvement of the toughness of the steel.
\end{abstract}

\section{INTRODUCTION}

Advanced high strength steels (AHSS), including dual phase, TRIP and martensitic grades, are being applied to new vehicle programs because of their contribution to efficient, mass-optimised vehicle structures. Improvements to the energy absorption, durability and structural strength of body structures result from increased usage of advanced high strength steels. Two major drivers for the use of newer steels in the automotive industry is fuel efficiency and increased safety performance. Fuel efficiency is mainly a function of weight of steel parts, which in turn, is controlled by gauge and design. Safety is determined by the energy absorbing capacity of the steel used to make the part. The most common AHSS is the dualphase steel that consists of a ferrite-martensite microstructure. These steels are characterized by high strength, good ductility, low tensile to yield strength ratio and high bake-hardenability. Another class of AHSS is the multi-phase steel which have a complex microstructure consisting of various phase constituents and a high yield to tensile strength ratio. Transformation Induced Plasticity (TRIP) steels is the latest class of AHSS steels finding interest among the U.S. automakers. These steels consist of a ferrite-bainite microstructure with significant amount of 
International Journal of Design and Manufacturing Technology (IJDMT), ISSN 0976 - 6995(Print), ISSN 0976 - 7002(Online) Volume 4, Issue 3, September - December (2013), ( IAEME

retained austenite phase and show the highest combination of strength and elongation, so far, among the AHSS in use.

Different rates of cooling provide different degree of driving force for the transformation of austenite. While phase transformation in continuously cooled low carbon microalloyed steel is mechanistically transient [1- 6], the steel cooled at different cooling rates are expected to yield different types of multiphase microstructures. In order to understand the evolution of microstructures of these steels during continuous cooling at different rates, the constructions of a CCT diagram and the resultant microstructural mapping at various cooling rate is required.

Hence the present investigation has envisaged the construction of the CCT diagram of a microalloyed steel and the study of microstructures attainable at different cooling rates. In anticipation of the probable change in the kinetics of austenite transformation at low temperatures, due to change in alloys chemistry

\section{EXPERIMENTAL} below

The chemical composition of the steels used for the present investigation is furnished

Table 1.Chemical composition of the experimental steels (weight \%)

\begin{tabular}{|c|c|}
\hline Elements & Weigh Percentage \\
\hline $\mathrm{C}$ & 0.10 \\
\hline $\mathrm{Mn}$ & 0.65 \\
\hline $\mathrm{Cr}$ & 0.60 \\
\hline $\mathrm{Si}$ & 0.40 \\
\hline $\mathrm{Al}$ & 0.03 \\
\hline $\mathrm{Cu}$ & 0.70 \\
\hline $\mathrm{Mo}$ & 0.30 \\
\hline $\mathrm{V}$ & 0.03 \\
\hline $\mathrm{S}$ & 0.008 \\
\hline $\mathrm{P}$ & 0.007 \\
\hline
\end{tabular}

The experimental steel samples were heated to $950^{\circ} \mathrm{C}$ i.e. above $\mathrm{A}_{\mathrm{C} 1}$ temperature and soaked for one hour in a Gleeble thermomechanical simulator. These were then cooled at different cooling rates i.e. $0.5^{\circ} \mathrm{C} / \mathrm{sec}, 1^{\circ} \mathrm{C} / \mathrm{sec}, 3^{\circ} \mathrm{C} / \mathrm{sec}, 10^{\circ} \mathrm{C} / \mathrm{sec}, 20^{\circ} \mathrm{C} / \mathrm{sec}, 30^{\circ} \mathrm{C} / \mathrm{sec}, 40^{\circ} \mathrm{C} / \mathrm{sec}$ and $80^{\circ} \mathrm{C} / \mathrm{sec}$.

\section{A. Construction of CCT diagram}

The Gleeble thermomechanical simulator has been used to construct the CCT diagram of the steel. Dilatometric measurements were used to monitor the start and finish of the transformation of austenite at different cooling rates. Detailed microstructural studies have been carried out to study the evolution of microstructures in the above continuously cooled steel.

\section{B. Mechanical Properties}

Mechanical properties of the microalloyed steel is shown in the table 2 
International Journal of Design and Manufacturing Technology (IJDMT), ISSN 0976 - 6995(Print), ISSN 0976 - 7002(Online) Volume 4, Issue 3, September - December (2013), @ IAEME

Table: 2 Mechanical properties of experimental steel

\begin{tabular}{|l|c|c|c|c|}
\hline S1 No. & $\begin{array}{l}\text { Cooling rate } \\
\left({ }^{\circ} \mathrm{C} / \mathrm{sec}\right)\end{array}$ & UTS (MPa) & $\begin{array}{l}\text { Elongation } \\
\%\end{array}$ & $\begin{array}{l}\text { Hardness } \\
(\mathrm{VHN})\end{array}$ \\
\hline 1 & 15 & 790 & 26 & 232 \\
\hline 2 & 40 & 780 & 32 & 227 \\
\hline
\end{tabular}

\section{RESULTS AND DISCUSSION}

The microstructural studies on the experimental steel under the situation of continuous cooling at various rates reveal the transient character of phase transformation in low carbon steels with minor additions. The description of microstructures made herein follows from the recommended nomenclature of ISIJ Bainite committee [7].

Polygonal ferrite, $\alpha_{p}$ is, in general, present in the microstructure of the steel for a cooling rate $0.5^{\circ} \mathrm{C} / \mathrm{sec}$ (Fig.1); however occasional presence of pearlite has been observed in the sample. The selected area diffraction pattern (SADP) matrix at the inset confirms the presence of $\mathrm{BCC}$ ferrite $(B=[123])$. TEM picture at higher resolution has given the evidence of fine precipitates, presumably of microalloyed carbides and copper, Fig.2. It is demonstrated elsewhere that copper is highly prone to be precipitated within ferrite unless austenite to ferrite transformation temperature is lowered to the level where diffusion of copper is extremely sluggish [4].

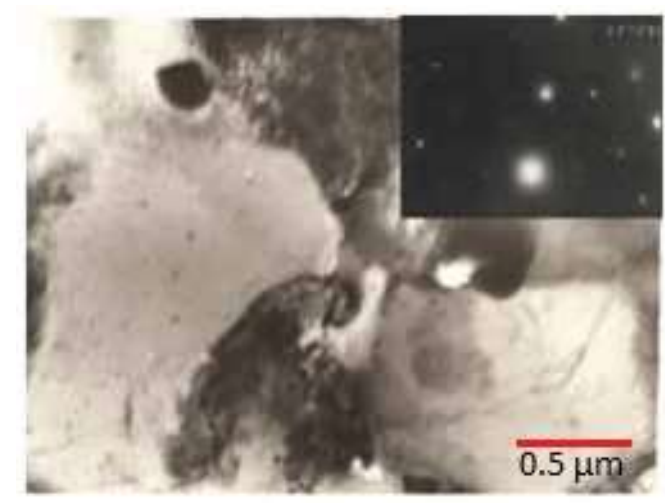

Fig. 1TEM photograph of steel for cooling rate, $0.5^{\circ} \mathrm{C} / \mathrm{sec}$ showing polygonal ferrite

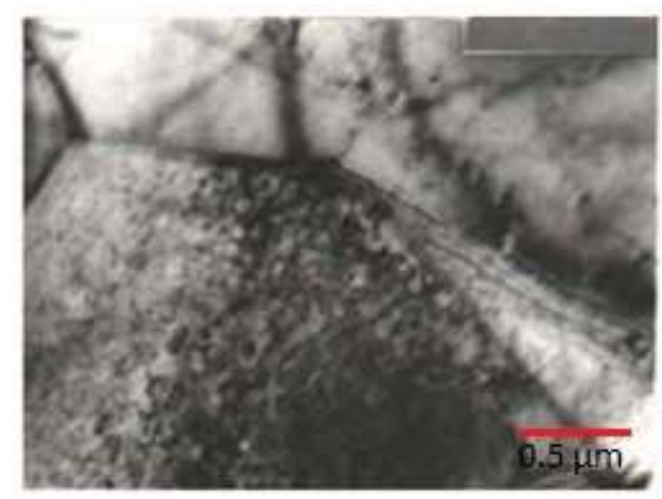

Fig. 2 TEM photograph of steel showing fine precipitates and microalloyed carbides

Cooling of the steel at $1^{\circ} \mathrm{C}$ has brought about detectable changes in the microstructure. Due to slightly higher rate of cooling the mixed mode of transformation of austenite is evidenced in microstructure. While Fig. 3 shows the presence of both widmanstatten, $\alpha_{w}$ and polygonal ferrite $\alpha_{p}$, the TEM picture from some other location of samples cooled at $1{ }^{\circ} \mathrm{C} / \mathrm{sec}$ gives the ferritic region with ample granular constituent (Fig.4). The dark field photograph clearly rules out the possibility that those second phase constituent in bright field images are the precipitates of microalloyed carbide and/or copper (Fig.5). However, these granular constituent closely resemble granular MA constituents within the ferrite as reported by previous investigators [7]. These type of microstructures, by virtue of it corroborating previous report is described as granular ferrite/granular bainite. Hence, at this cooling rate, the microstructure of the steel comprises of $\alpha_{w}, \alpha_{p}$ and $\alpha_{B}^{\mathrm{o}}$. During continuous cooling transformation takes place at different temperatures. Depending upon the driving energies 
International Journal of Design and Manufacturing Technology (IJDMT), ISSN 0976 - 6995(Print), ISSN 0976 - 7002(Online) Volume 4, Issue 3, September - December (2013), @ IAEME

available at various transformation temperature different transformation mode is operates within the system. The SADP at the inset of Fig. 4 confirmed BCC structure.

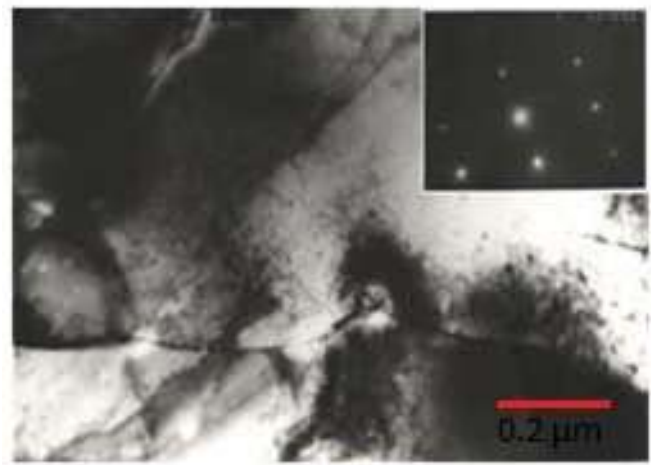

Fig. 3 TEM photograph of steel for cooling rate, $1^{\circ} \mathrm{C} / \mathrm{sec}$ showing widmanstatten and polygonal ferrite

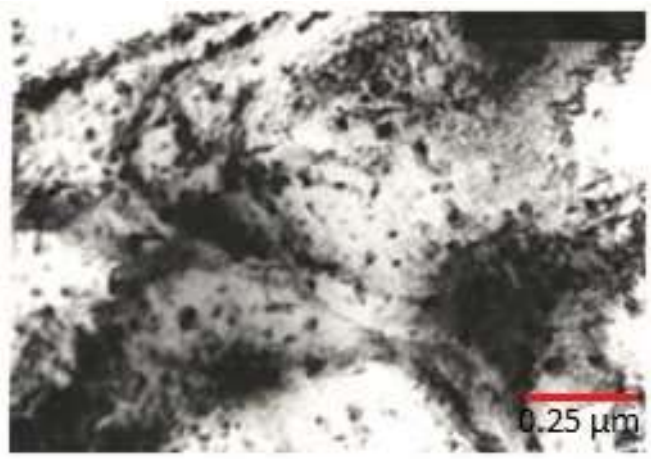

Fig. 4 TEM photograph of the steel showing ample granular constituents in the ferritic region

CCT diagram of the experimental steel is found to be flat over a wide range of cooling rates from $5^{\circ} \mathrm{C} / \mathrm{sec}$ till $40^{\circ} \mathrm{C} / \mathrm{sec}$ (Fig.6). It is seen from Fig. 6 that the transformation of austenite starts at a temperature $600^{\circ} \mathrm{C}$ and progresses continuously upto $300^{\circ} \mathrm{C}$. At higher temperature of transformation, granular bainite forms through ledge mechanism [7], whereas, the remaining austenite transforms at lower temperature and produces acicular bainite $\left(\alpha_{B}\right)$. Thus the microstructure of the steel cooled at a rate of $10^{\circ} \mathrm{C} / \mathrm{sec}$ is comprised of granular bainite $\alpha_{\mathrm{B}}^{\mathrm{o}}$ and acicular bainite $\alpha_{\mathrm{B}}$. It is further noted when the transformation takes place at higher temperature and at such low cooling rate of $10 \% \mathrm{sec}$, extensive precipitation of copper takes place (Fig.7). The SADP at the inset shows ring pattern, which is indication of the existence of very fine precipitates huge in number; the indexing of ring pattern verifies the precipitates as of FCC structure and thus it is conjectured that cooling at $10^{\circ} \mathrm{C} / \mathrm{sec}$ envisages precipitation of copper within granular bainite.

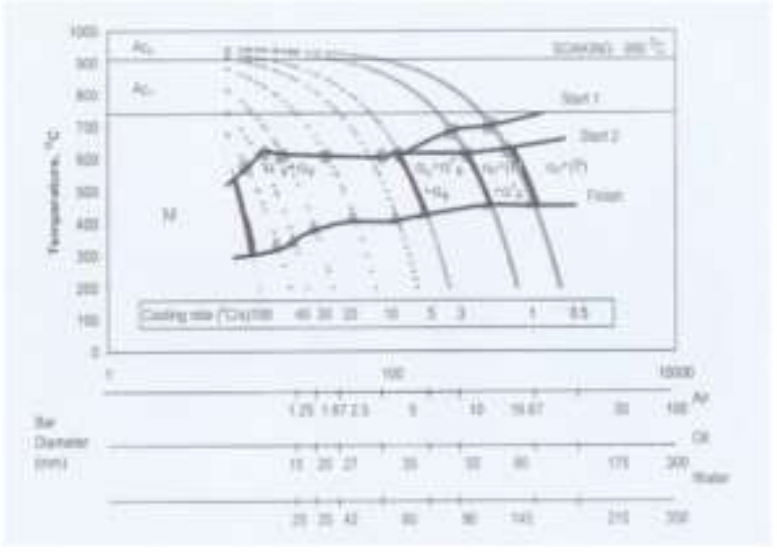

Fig. 6 CCT diagram of the experimental steel

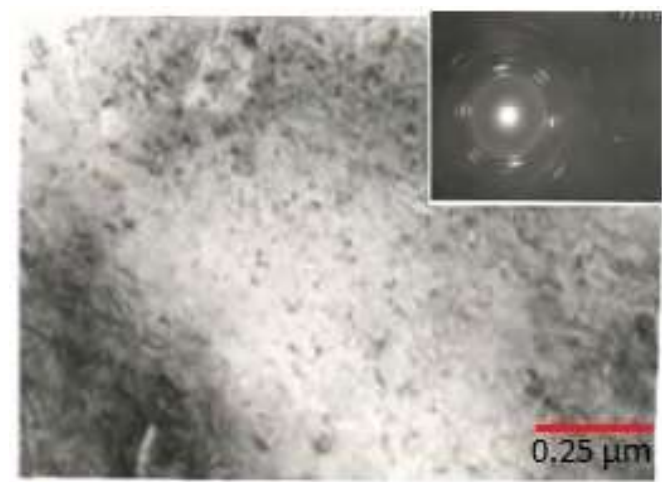

Fig. 7 TEM photograph of steel for cooling rate $10^{\circ} \mathrm{C} / \mathrm{sec}$ showing copper precipitates and SADP in the inset showing ring pattern 
International Journal of Design and Manufacturing Technology (IJDMT), ISSN 0976 - 6995(Print), ISSN 0976 - 7002(Online) Volume 4, Issue 3, September - December (2013), ( IAEME

It is further reveals from CCT diagram that an increase in cooling rate to $21^{\circ} \mathrm{C} / \mathrm{sec}$ may not give rise to any significant change in transformation behaviour because of the flatness of the diagram. Nevertheless faster cooling reduces the gap between transformation start and finish lines. Therefore the microstructure is expected to be dominated by the acicular bainite (Fig.8). It is further observed therein that the bainite is highly dislocated and considerable amount of precipitates of different morphologies are seen to exist in the microstructure. It is surmised that the needle shaped precipitates on dislocations are of carbides of chromium. The steel cooled at $44^{\circ} \mathrm{C} / \mathrm{sec}$ is seen to be produced primarily acicular bainite. At the lath boundaries of bainite ferrite black constituent of irregular morphology is seen. These MA constituents are seeming retained austenite. The dark field photograph also gives evidence of the presence of chunky MA constituent, which is supposed to be carbon enriched austenite retained due to incomplete bainite reaction (Figs. 9, 10).

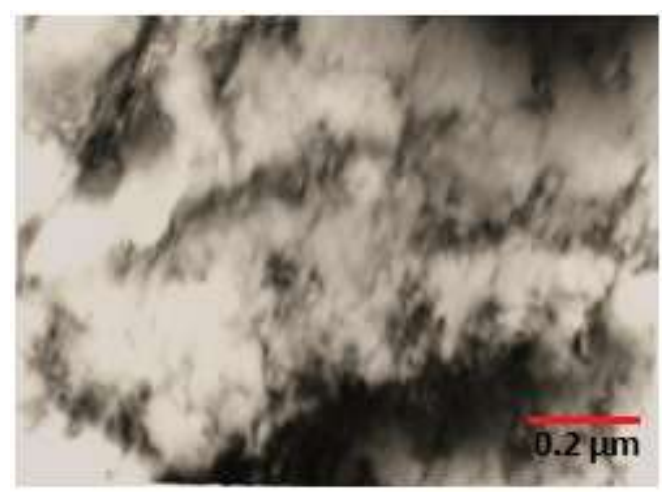

Fig. 8 TEM photograph of steel for cooling rate $44^{\circ} \mathrm{C} / \mathrm{sec}$ showing acicular bainite and retained austenite

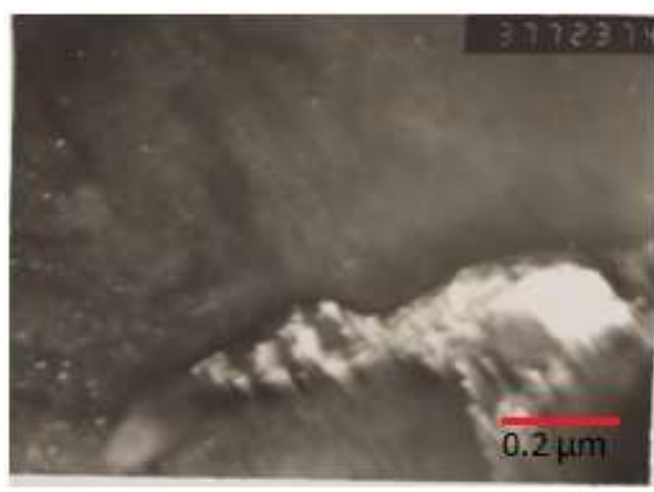

Fig. 10 TEM photograph of steel for cooling rate $44^{\circ} \mathrm{C} / \mathrm{sec}$ showing chunky MA constituent

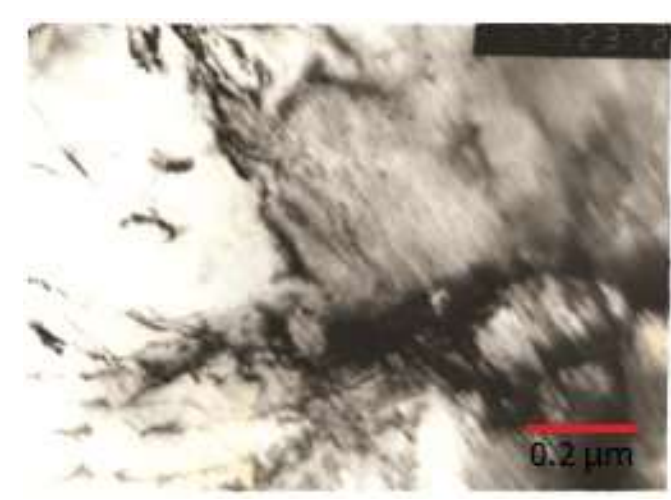

Fig. 9 TEM photograph of steel for cooling rate $44^{\circ} \mathrm{C} / \mathrm{sec}$ showing chunky MA constituent

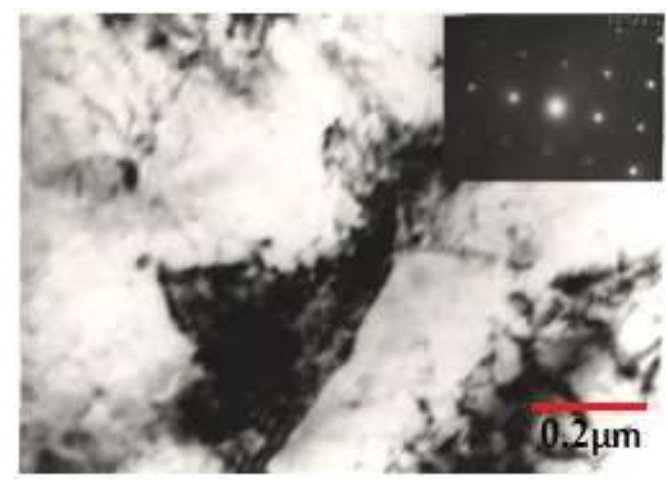

Fig. 11 TEM photograph of steel for cooling rate $80^{\circ} \mathrm{C} / \mathrm{sec}$ showing martensite and acicular bainite with chunky MA constituent

Further increase in cooling rate leads to formation of martensite and/or acicular bainite with irregular and chunky MA constituent in the microstructure (Fig.11). The presence of precipitation of copper observed at high resolution signifies that copper has been precipitated spontaneously (Fig-12). In an earlier kinetic analysis on similar steel had demonstrated that 
International Journal of Design and Manufacturing Technology (IJDMT), ISSN 0976 - 6995(Print), ISSN 0976 - 7002(Online) Volume 4, Issue 3, September - December (2013), @ IAEME

copper undergoes precipitation from austenite spontaneously and can not be retained in solid solution unless transformation temperature is made sufficiently low.

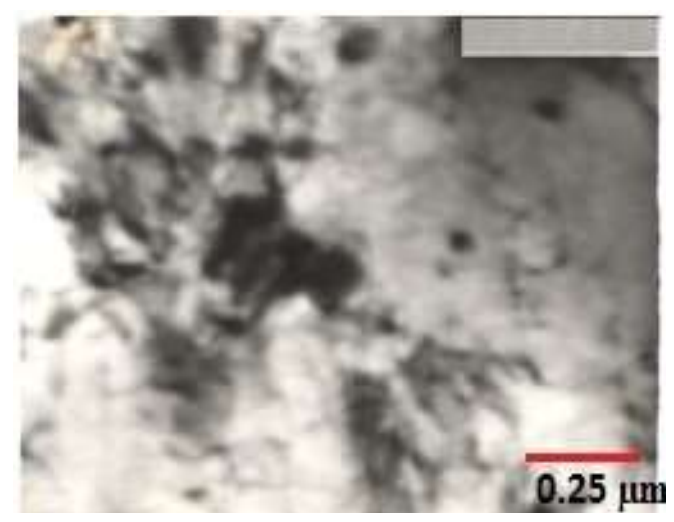

Fig. 12 TEM photograph of steel for cooling rate $80^{\circ} \mathrm{C} / \mathrm{sec}$ showing copper precipitates at higher resolution

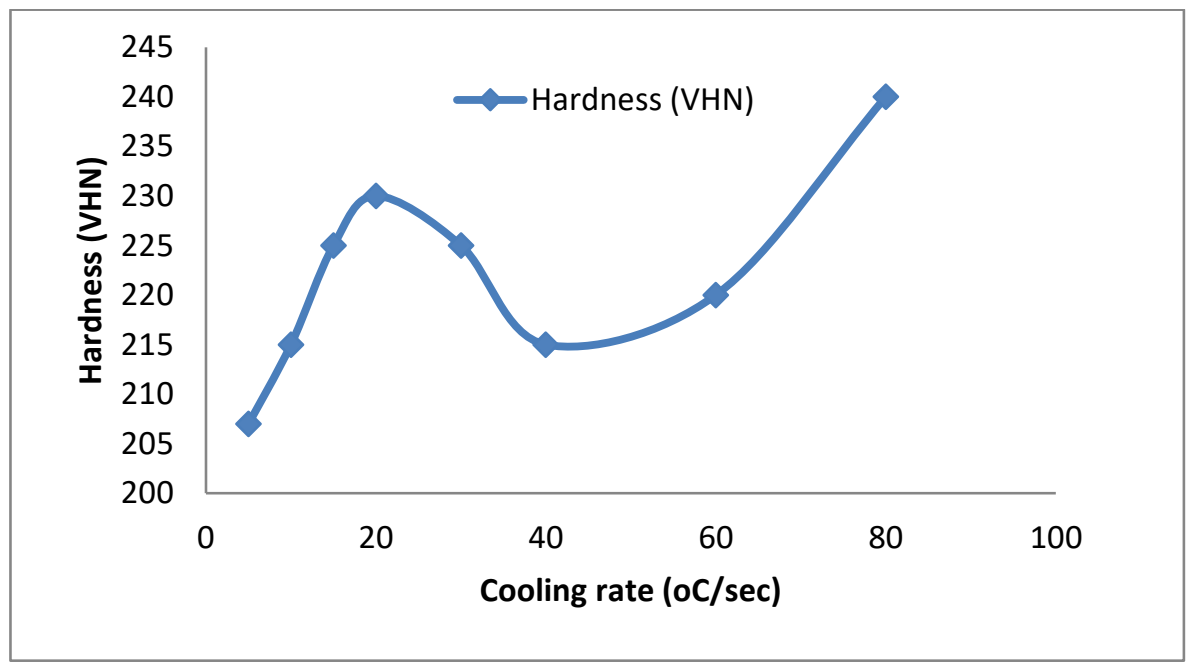

Fig. 13 Variation in hardness of the experimental steel with cooling rate

The variation of hardness of the steel with cooling rate is seen to directly follow from the microstructural evidences. The initial increase in hardness, Fig.13, is due to increase in acicular bainite content in the microstructure. This is because of availability of higher driving energy at higher cooling rate. Beyond $20^{\circ} \mathrm{C} / \mathrm{sec}$ hardness value of the steel is seen to decrease; it may be noted that as cooling rate increases, solute enriched austenite finds it more difficult to get relieved from super saturation to allow bainitic transformation to proceed. So amount of retained austenite becomes appreciably high in the microstructure, this results in drop in hardness. The increase in percentage elongation without much sacrifice in strength (Table 2) owes its origin to the presence of retained austenite, which, it is anticipated, undergoes stress induced martensitic transformation upon loading, thereby insuring ductility enhancement through TRIP phenomenon. 
International Journal of Design and Manufacturing Technology (IJDMT), ISSN 0976 - 6995(Print), ISSN 0976 - 7002(Online) Volume 4, Issue 3, September - December (2013), ( IAEME

\section{CONCLUSION}

The authors wish to conclude that the flat CCT diagram of the experimental steels over a range of cooling rates ensures phase transformation which is mechanistically transient under continuous cooling. The multiphase microstructures of the continuously cooled steels are constituted primarily by granular bainite and acicular bainite. The fraction of acicular bainite increases with cooling rate $\sim 40^{\circ} \mathrm{C} / \mathrm{sec}$, the carbon enriched austenite is retained in the chunky form in the microstructure. This retained austenite account for the observed drop in hardness around intermediate cooling rate. It is further concluded that precipitation if copper is inhibited niobium added steels due to lowering of austenite ferrite transformation temperature.

\section{REFERENCES}

[1] M. K. Banerjee, P. S. Banerjee, S. Datta, Effect of Thermomechanical Processing on the Microstructure and Properties of a Low Carbon Copper Bearing Steel, ISIJ International, 2001, Volume 41, Issue 3, Pages 257-261. https://doi.org/10.2355/isijinternational.41.257

[2] Banerjee, M.K., Ghosh, D. and Datta, S. (2000), Effect of composition and thermomechanical processing on the ageing characteristic of copper-bearing HSLA steel. Scandinavian Journal of Metallurgy, 29: 213-223. https://doi.org/10.1034/j.1600-0692.2000.d01-25.x

[3] Naoki Maruyama, Masaaki Sugiyama, Takuya Hara, Hiroshi Tamehiro, Precipitation and Phase Transformation of Copper Particles in Low Alloy Ferritic and Martensitic Steels, Materials Transactions, JIM, 1999, Volume 40, Issue 4, Pages 268-277. https://doi.org/ 10.2320/matertrans 1989.40.268

[4] Galibois, A., Krishnadev, M.R. \& Dubé, A. Control of grain size and sub-structure in plain carbon and high strength low alloy (HSLA) steels-the problem and the prospect. Metall Mater Trans A 10, 985-995 (1979). https://doi.org/10.1007/BF02811645

[5] Anthony J. DeArdo, Multi-phase Microstructures and Their Properties in High Strength Low Carbon Steels, ISIJ International, 1995, Volume 35, Issue 8, Pages 946-954. https:// doi.org/10.2355/isijinternational.35.946

[6] J. Y. Yoo, W. Y. Choo, T. W. Park, Y. W. Kim, Microstructures and Age Hardening Characteristics of Direct Quenched Cu Bearing HSLA Steel, ISIJ International, 1995, Volume 35, Issue 8, Pages 1034-1040. https://doi.org/10.2355/isijinternational.35.1034

[7] George Krauss, Steven W. Thompson, Ferritic Microstructures in Continuously Cooled Low- and Ultralow-carbon Steels, ISIJ International, 1995, Volume 35, Issue 8, Pages 937-945. https://doi.org/10.2355/isijinternational.35.937

[8] Bhadeshia H. K. D. H. Bainite in Steels : Transformations Microstructure and Properties. 2nd ed. IOM Communications 2001.

[9] Sreekala P and Visweswararao K, "A Methodology for Chip Breaker Design at Low Feed Turning of Alloy Steel using Finite Element Modeling Methods", International Journal of Mechanical Engineering \& Technology (IJMET), Volume 3, Issue 2, 2012, pp. 263 - 273, ISSN Print: 0976 - 6340, ISSN Online: 0976 - 6359. 